\title{
Improving Seismic Performance of Structure with Semi-rigid floor using VSL-Gensui Damper
}

\author{
Pudjisuryadi, P. ${ }^{1}$, Halim, A. ${ }^{1 *}$, Kandiawan, A.K. ${ }^{1}$, and Lumantarna, B. ${ }^{1}$
}

\begin{abstract}
Seismic performance of structures can be improved using various methods. In this study, Vorspann System Losinger (VSL) Gensui Damper is used to improve the seismic performance of building with semi-rigid floors. Spectrum consistent ground accelerations is generated from El Centro May 19th, 1940 earthquake per SNI 1726:2012 for Mataram, Indonesia. Modified Simplified Sequential Search Algorithm (MSSSA) and Optimum Damper Allocation Method (ODAM) are used to efficiently place the dampers on the building to meet certain criteria. Uniform placement which is used as the first step of ODAM is used for comparison. The results show that both methods can effectively reduce structural drifts and damages. MSSSA shows slightly better performance since ODAM has a limitation that dampers can only be swapped among stories of the initially chosen frames. It is also noted that the dampers must be well distributed among frames in the same story, to take care the different drifts in building with semirigid floors.
\end{abstract}

Keywords: Drift; damper placement method; non-linear time history analysis; semi-rigid floors; strengthening; VSL Gensui damper.

\section{Introduction}

In seismically active countries such as Indonesia, consideration of earthquake load in building design is imperative. Indonesia has SNI 1726:2012 [1], as its guidelines for designing structures to withstand earthquake load. In conjunction with structural codes such as concrete design code (SNI 2847:2013) [2] and steel design code (SNI 1729:2015), the Indonesian Seismic Code (SNI 1726:2012) should be used to ensure buildings capability to withstand earthquakes.

One of the most common criteria that are not accurately assumed is floor rigidity. In SNI 1726 : 2012, there is a clause which states "Diaphragms of concrete slabs or concrete filled metal deck with spanto-depth ratios of 3 or less in structures that have no horizontal irregularities are permitted to be idealized as rigid" [1,3]. However, in buildings with concrete slabs, rigid floor diaphragm is usually assumed regardless of the large diaphragm span-to-depth ratio. This may cause inaccurate story drifts in the building model [4]. In the effort of improving the seismic performance of existing structures, many techniques can be used, and one of them is by installing dampers.

1 Faculty of Civil Engineering and Planning, Civil Engineering Department, Petra Christian University, Л. Siwalankerto 121-131, Surabaya 60236, INDONESIA

*Corresponding author; Email: m21416087@petra.ac.id

Note: Discussion is expected before November, $1^{\text {st }} 2020$, and will be published in the "Civil Engineering Dimension", volume 23, number 1, March 2021.

Received 14 July 2020; revised 10 August 2020; accepted 10 August 2020.
Damper is an energy dissipation system that can be installed in a structure. The use of energy dissipation systems for an earthquake-resistant structure is useful for improving the seismic performance of a structure [5,6]. In this study, a type of damper produced by Vorspann System Losinger (VSL), namely VSL Gensui Damper, is used to improve the seismic performance of an elongated structure. VSL Gensui Damper is a wall type viscoelastic damper that consists of multilayers of rubber and steel that has $400 \times 400 \times 15 \mathrm{~mm}$ in dimension (Figure 1). To maximize the benefit of using dampers while still paying good attention to the cost induced, strategic placement of dampers is a must.

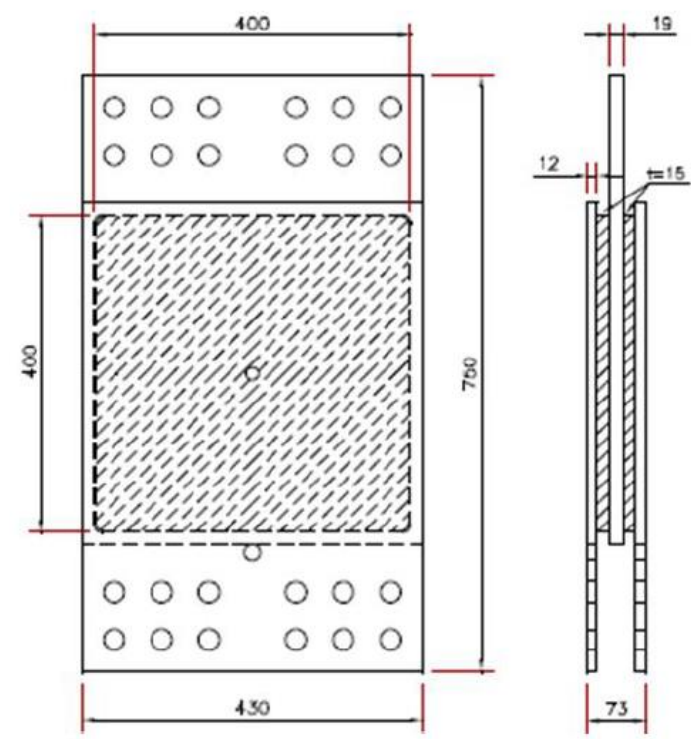

Figure 1. VSL-Gensui Damper 


\section{Strategic Placement of dampers}

Two damper placement strategies are used in this study. As the first strategy, Simplified Sequential Search Algorithm (SSSA) [7] is adopted. In this case, the proposed modification of SSSA by Angkasaputra and Sebastiano [8] is used, in which the original damper placement indicator of SSSA is modified by only considering story drift and neglecting story velocity. Hereafter the modification is called as the Modified Simplified Sequential Search Algorithm (MSSSA). The second strategy used is Optimum Damper Allocation Method (ODAM) [9]. The uniform damper placement which is the initial step of the ODAM method is used for comparison against the previous two methods. In a previous research Andini and Goenawan [10], studied the two methods on a simple structure and concluded that both ODAM and MSSSA are effective in reducing interstory drift.

In ODAM, the total number of dampers used is decided from the beginning, and typically the dampers are placed at every story of selected frames. Then the dampers in the story with minimum drift will be moved to the floor with maximum drift. This process is repeated until certain acceptance criteria are met, or the last two damper relocations indicate swaps between the same two stories. In the MSSSA method, each damper addition is placed at the story with the largest drift in the selected frames. The damper addition is stopped when certain acceptance criteria are met. In this study, the maximum story drift ratio of the structure is targeted to be less than $0.4 \%$. Meanwhile, the average damage index of the structure is targeted to be reduced as much as $25 \%$ and $35 \%$ for earthquakes with scheme $\mathrm{Y}$ and scheme $\mathrm{X}$, respectively. Scheme $\mathrm{Y}$ and $\mathrm{X}$ represent the dominant earthquake in the $\mathrm{Y}$ and $\mathrm{X}$ direction corresponding to the building. For a comparable comparison between the methods, the number of the dampers on all method is determined to be 44 dampers and 16 dampers, for schemes $\mathrm{Y}$ and $\mathrm{X}$, respectively.

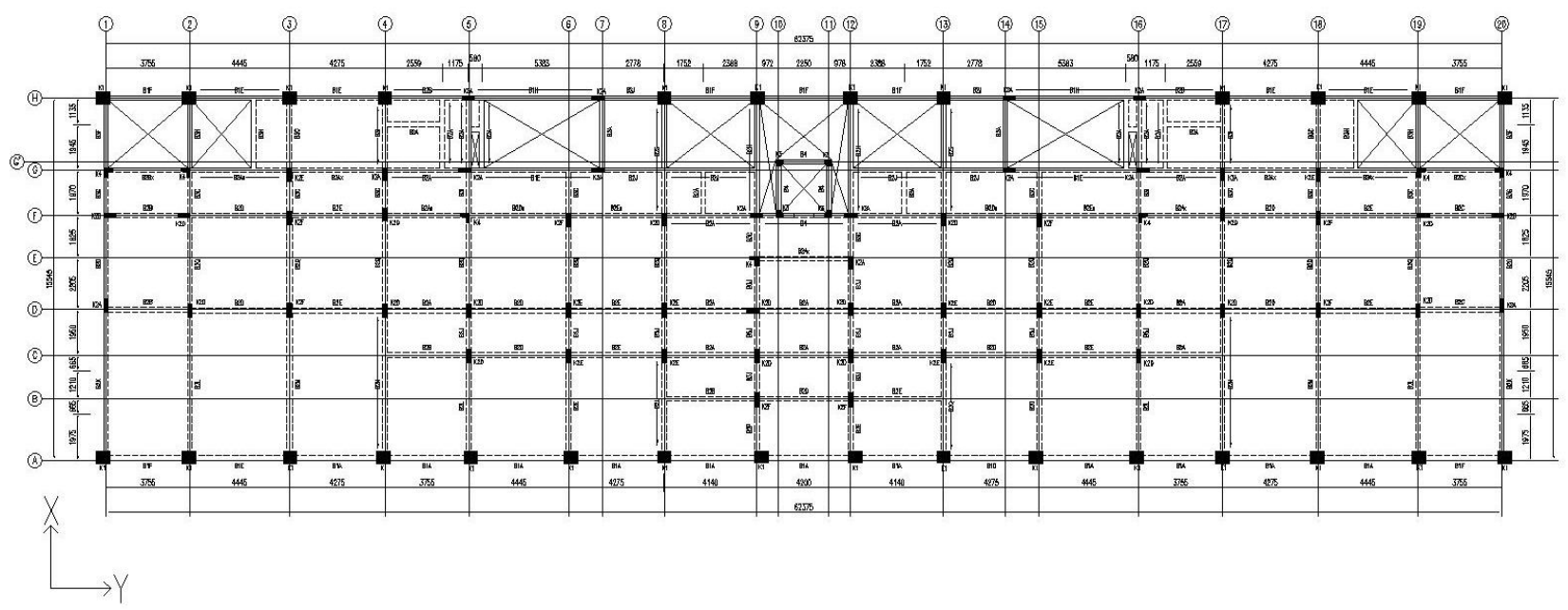

Figure 2. Typical Floor Plan (1 $1^{\text {st }}$ floor $-3^{\text {rd }}$ floor $)$

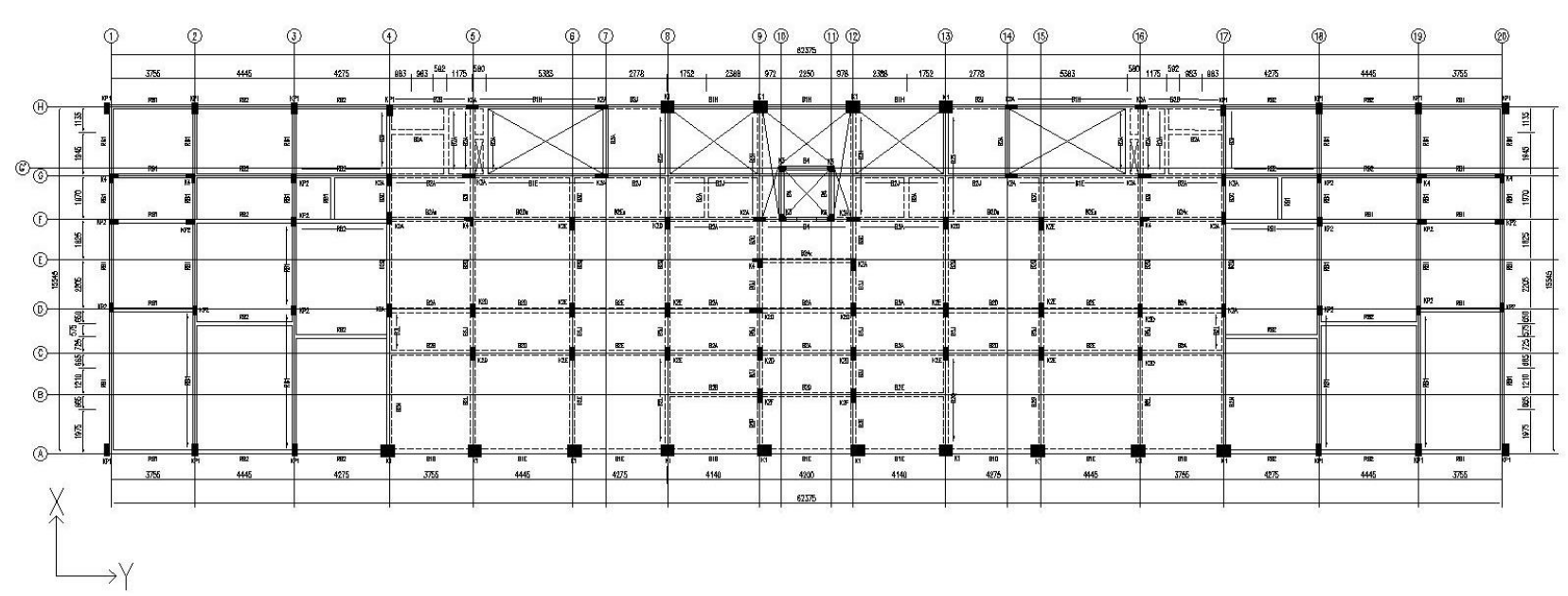

Figure 3. Floor Plan of the $4^{\text {th }}$ Floor 


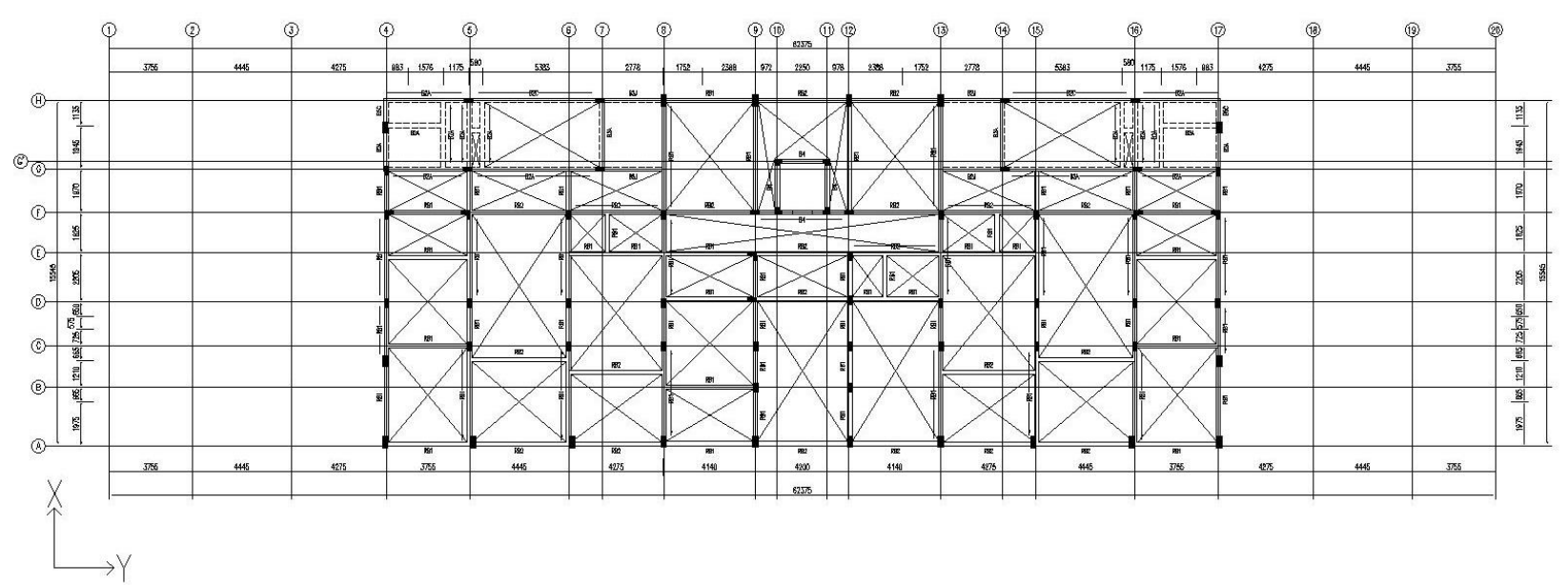

Figure 4. Floor Plan of the Roof Floor

\section{Considered Structure}

An existing hotel located in Mataram, Indonesia, is chosen to be studied. This five-story building has 14 meters height and 62.3 meters by 15.5 meters floor plan dimension resulting in span-to-depth ratio larger than 3.0 which requires semi-rigid floor assumption to obtain accurate building deformation [1]. The floor plan of the typical $1^{\text {st }}$ to $3^{\text {rd }}$ floor, $4^{\text {th }}$ floor, and roof floor can be seen in Figures 2, 3, and 4, respectively.

\section{Modeling of the Structure and Analysis}

Computer software SAP2000 [11] is used to model the existing structure, as shown in Figure 5. The autohinge feature of SAP2000 is used to determine the non-linear hinges properties of all beams and columns.

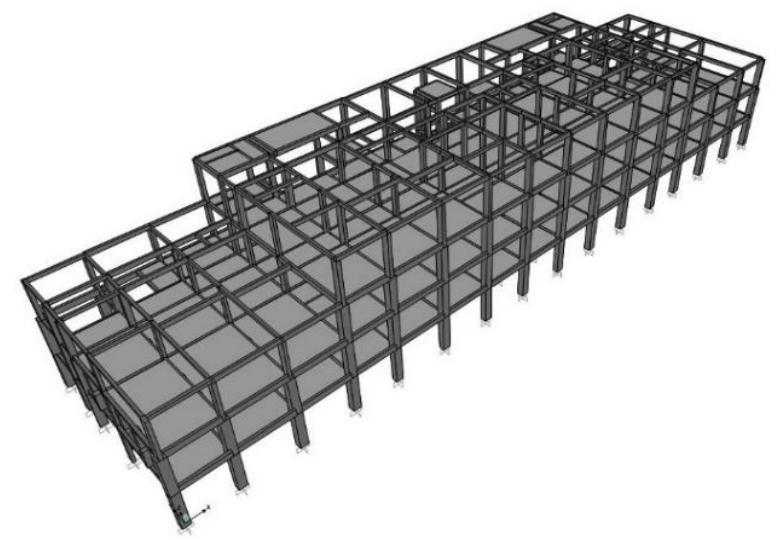

Figure 5. Modeling of Existing Building in SAP2000

The ground-motions records used for the analysis are The Imperial Valley earthquake, recorded at El Centro station, May 19th, 1940, obtained from the Pacific Earthquake Engineering Research (PEER). These Ground-motions are matched to Mataram's Maximum Considered Earthquake (MCE) response spectrum. MCE is a 2500-year return period earthquake and is 1.5 times greater than the Elastic Design Earthquake (EDE), which is required by SNI
1726:2012 for designing an earthquake-resistant structure. Imperial Valley's PGA in East-West (EW) and North-South (NS) direction is $0.21 \mathrm{~g}$ and $0.281 \mathrm{~g}$, respectively, which can be seen in Figure 6. To maintain the PGA ratio of the Imperial Valley earthquake in both directions, the original NS and EW ground accelerations are matched to $100 \%$ and $70 \%$ of Mataram's MCE, respectively. The modified ground acceleration is presented in Figure 7. In this study, spectrum consistent EW and NS ground motions are subjected to the building twice. First, the NS and EW component is applied in the $\mathrm{Y}$ and $\mathrm{X}$-axis of the building, respectively. Then the directions of the two components are switched to ensure the most severe case is analyzed in both orthogonal directions.

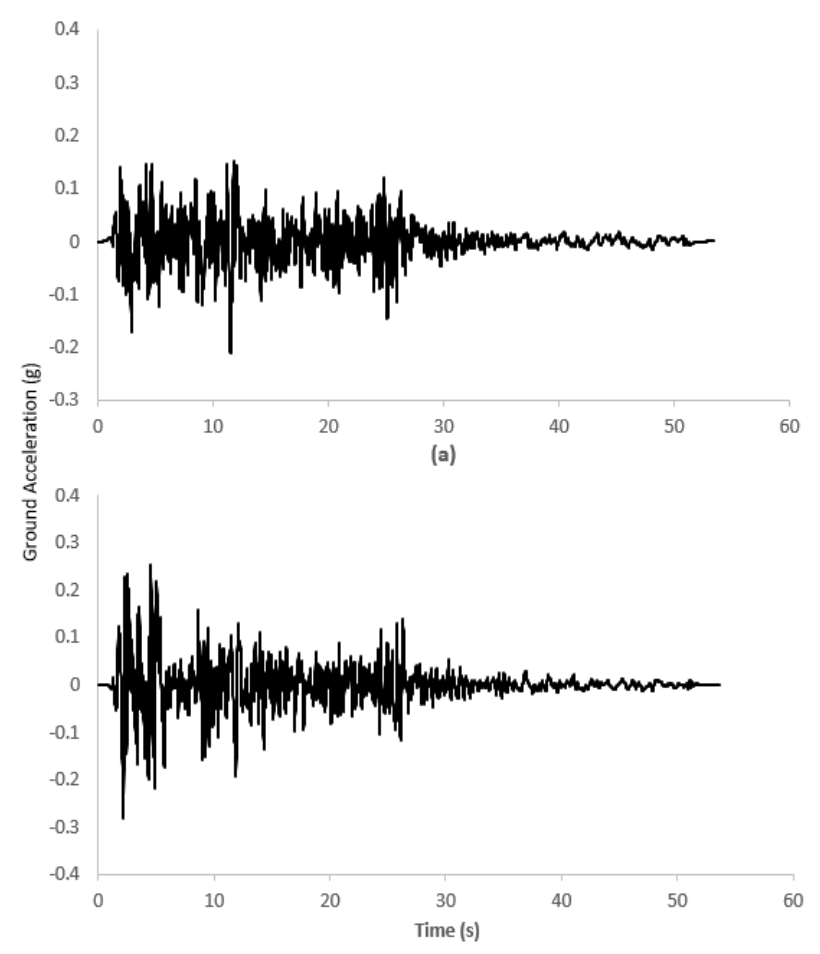

(b)

Figure 6. Imperial Valley Earthquake Ground Accelerations: (a) EW Component; (b) NS Component 


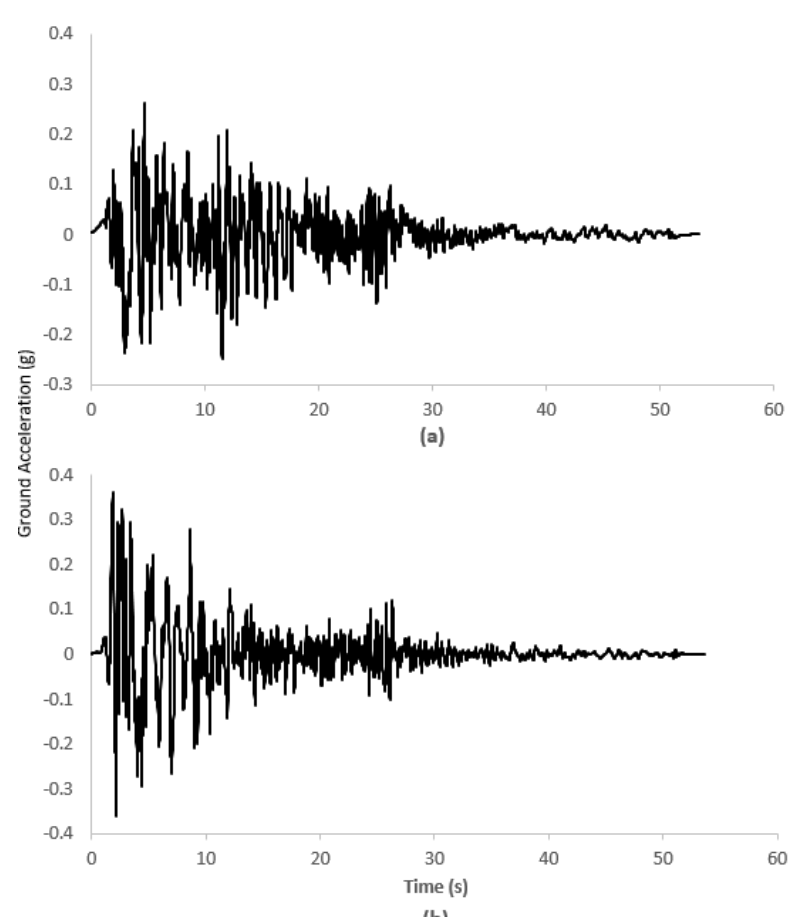

(b)

Figure 7. Modified Imperial Valley Earthquake ground accelerations: (a) EW Component; (b) NS Component

VSL Gensui Damper is modeled as non-linear link property with plastic wen type. There are several parameters that need to be calculated, which are effective stiffness, effective damping stiffness, yield strength, and post-yield stiffness ratio. The parameters can be obtained by using several charts and equations [12].

\section{Analysis Result}

Structural performance can be determined from the story drift and damage index of the plastic hinges in the structure. Asian Concrete Model Code (ACMC) 2001 is used to determine the damage index classification of the plastic hinges [13]. The states of plastic hinge damages are Immediate Occupancy (IO), Life Safety (LS), Collapse Prevention (CP), and beyond $\mathrm{CP}$, which correspond to damage index values of $0-10 \%, 10 \%-25 \%, 25 \%-40 \%$, and $40 \%-100 \%$, respectively. In this study, to give a brief idea of overall damage of the structural elements, the damage indices are averaged. Mid-range values of each damage states are used, which correspond to $5 \%$, $17.5 \%, 32.5 \%$, and $70 \%$ for damages below IO, between IO and LS, between LS and CP, and beyond $\mathrm{CP}$, respectively. Figures 8 to 11 present the drifts of the structure with a certain number of dampers with MSSSA and ODAM placement strategies as well the $0.4 \%$ story drift ratio target of each floor used in this study (DR 0.4\%). In these figures, drifts of original structure (bare) and structure with a certain number of dampers which are distributed in all stories of selected frames (uniform) are also shown as comparison. Labels "X" and "Y" indicate the direction of the dominant NS earthquake component. Although a two-dimensional earthquake is used, dampers placement in schemes " $\mathrm{X}$ " and "Y" are analyzed separately. Figure 8 and 9 show drifts of structure with rigid $(\mathrm{R})$ floor assumption due to dominant ground motion in the $\mathrm{X}$ and $\mathrm{Y}$ directions, respectively. Figures 10 and 11 show drifts of structure with semirigid (SR) floor assumption due to dominant ground motion in the $\mathrm{X}$ and $\mathrm{Y}$ directions, respectively. MSSSA and ODAM indicate the damper placement method used, while the numbers behind them show the number of dampers used. Uniform and Bare indicate the initial step of the ODAM method and original structure without any dampers installed, respectively. In Figures 8 to 11, "DR 0.4\%" represents the $0.4 \%$ story drift ratio target of each floor used in this study. It can be seen in Figures 8 and 11, that the number of dampers required to meet the drift target by using MSSSA method is less than that of ODAM method. MSSSA12 and MSSSA42 indicate that 12 and 42 dampers are sufficient to reach the target instead of 16 and 44 dampers which are required by ODAM method.

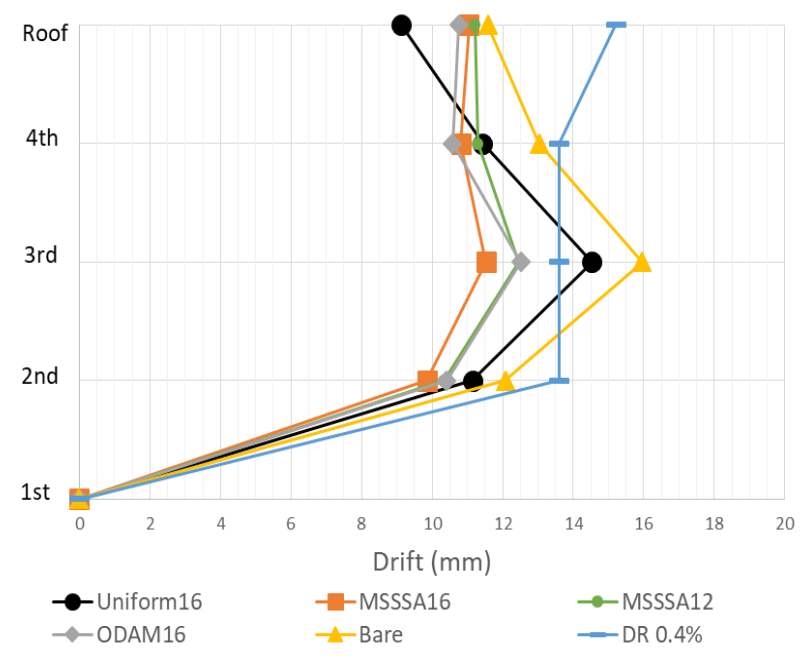

Figure 8. Drift in the X Direction of the Structure for R-X Case

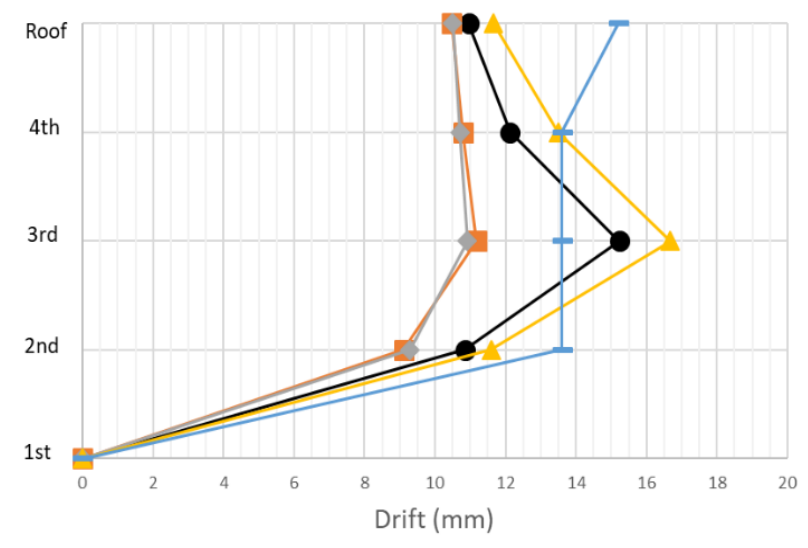

-Uniform44 --MSSSA44 $\rightarrow$-ODAM44 - $₫$-Bare -DR 0.4\%

Figure 9. Drift in the Y Direction of the Structure for R-Y Case 


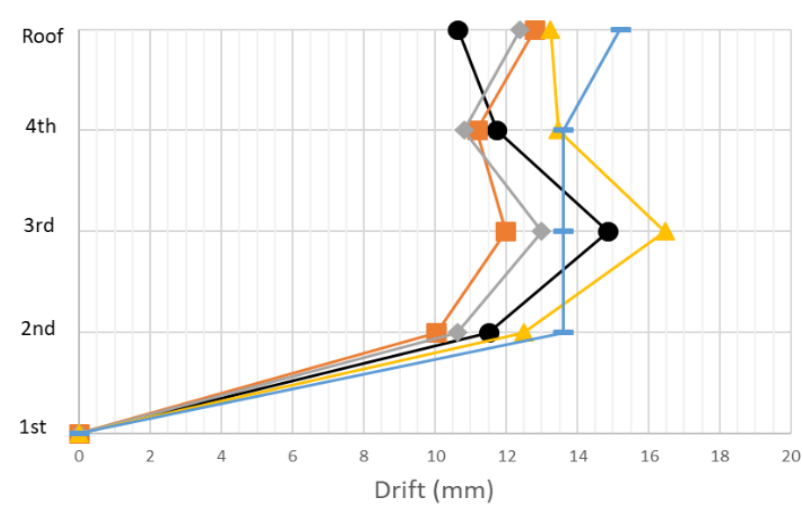

Uniform16 - MSSSA16 -ODAM16 - Bare - DR 0.4\%

Figure 10. Drift in the X Direction of the Structure for SR$\mathrm{X}$ Case

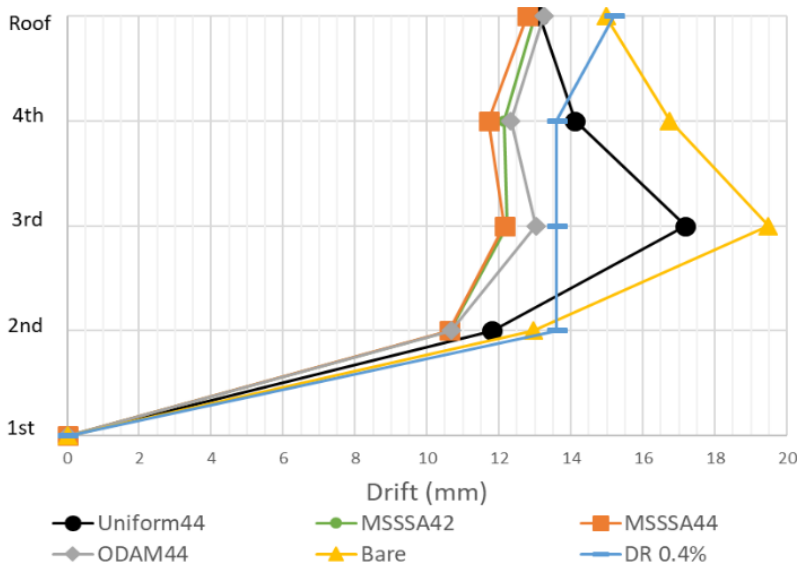

Figure 11. Drift in the Y Direction of the Structure for SRY Case

For cases using semi-rigid floor assumption (Figures 10 and 11), the plotted drifts are the maximum drift values among all frames of the structure. It can be seen from the figures that both ODAM and MSSSA succeeded in reducing the drift below the target. Despite using the same number of dampers installed (44 dampers and 16 dampers for scheme $\mathrm{Y}$ and scheme X, respectively), building with uniformly distributed dampers in all stories fails to reach the target.

The final placement of dampers in each placement method is presented in Figures 12 to 16, where the marks $\mathbf{O}$ and $\mathbf{X}$ indicate damper positions using MSSSA and ODAM placement, respectively. In Figures 12 to 16 , the dampers are always installed parallel to the marked frames. While the number of dampers installed on each floor can be seen on the caption of the figures shown.

It can be seen in Figure 13 that there are no dampers placed for MSSSA strategic placement because there is always larger drift on floor other than $4^{\text {th }}$ floors in every step of damper addition. However, some dampers may still exist on $4^{\text {th }}$ floor for the ODAM method since dampers are installed on each floor in its initial placement.

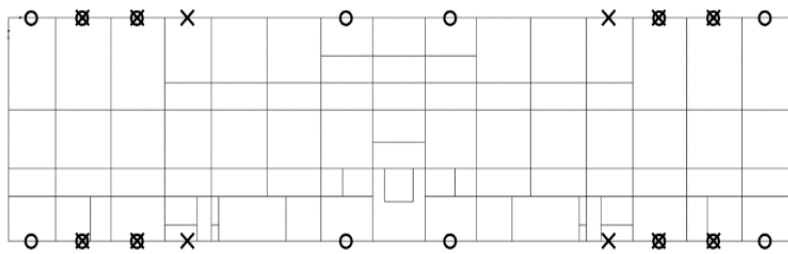

Figure 12. Damper Placement at $3^{\text {rd }}$ floor (R-X and SR-X); MSSSA: 16 dampers; ODAM: 12 dampers

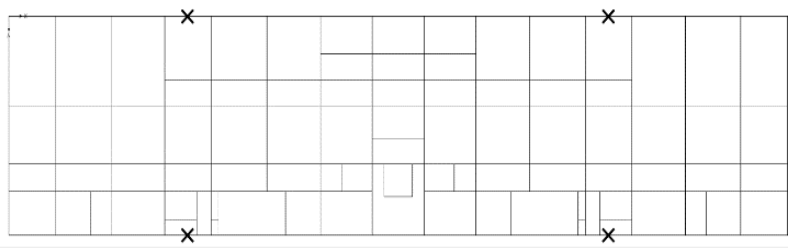

Figure 13. Damper Placement at $4^{\text {th }}$ floor (R-X and SR-X); MSSSA: 0 damper; ODAM: 4 dampers

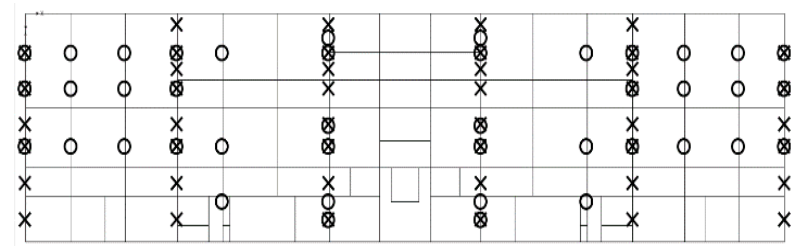

Figure 14. Damper Placement at $3^{\text {rd }}$ floor (R-Y); MSSSA: 44 dampers; ODAM: 44 dampers

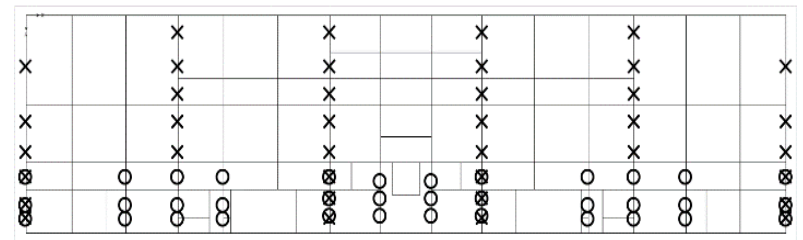

Figure 15. Damper Placement at $3^{\text {rd }}$ floor (SR-Y); MSSSA: 36 dampers; ODAM: 38 dampers

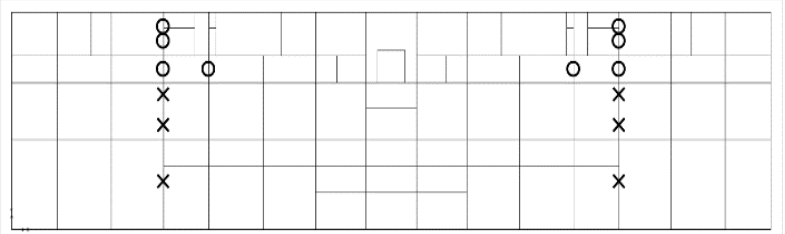

Figure 16. Damper Placement at $4^{\text {th }}$ floor (SR-Y); MSSSA: 8 dampers; ODAM: 6 dampers

The damage severity of the plastic hinges is presented in Tables 1 to 4 . In the tables, only B-IO hinges are displayed because there is no more severe hinge state than B-IO. In total, there are 2094 points of potential non-linear hinges assigned in the structure. More severe damages of structures using semi-rigid floor assumption are observed if compared to structures using rigid floor assumption indicated by increase of plastic damages. Due to dominant earthquake in the $\mathrm{Y}$ direction, the total number of plastic damages increases from 199 to 288,166 to 241,126 to 215 , and 115 to 192 in the case of bare, uniformly distributed dampers, MSSSA, and ODAM models, respectively (see Tables 2 and 4). This fact is also true in the case with dominant earthquake in the $\mathrm{X}$ direction (see 
Tables 1 and 3). Tables 1 to 4 also show that the application of dampers clearly reduces damages of the structure. For example, in the case of SR-Y (Table 4), the number of plastic hinges decreases from 288 in bare model to 215 and 192, in MSSSA and ODAM, respectively. However, at certain steps, the number of plastic hinges may increase, especially in ODAM, because the dampers are not added but moved among stories of the building. Uniformly distributed dampers do not reduce the damage as effective as both placement methods, as there are still 241 total plastic damages. It can be seen is earthquake scheme Y, where the deformations are still relatively large, ODAM and MSSA methods show much better performance compared to the structure with uniformly distributed dampers.

In this structure, there are significant differences from the results with semi-rigid and rigid floor assumption analysis. It is obvious that in a relatively large horizontal span dimension compared to its perpendicular, the concrete slab may not be rigid enough to simulate rigid body movement of the whole floor diaphragm. The results of the analysis with the semi-rigid model produce more severe drifts compared to that of the rigid floor model. The drift of frames in the same story may differ significantly in semi-rigid floor assumption, which is not the case in rigid floor assumption. The drift of frames information is very useful to determine damper placement throughout the study.

\section{Conclusion}

In this study, the effort to improve the seismic performance of a structure is conducted by installing VSL Gensui Dampers. The floor plan of the building has a large span to depth ratio that it should be analysed as semi-rigid floor. From non-linear time history analysis results, some conclusion can be made as follows:

1. More extreme story drifts are observed in structure analyzed by using semi-rigid floor assumption in the direction perpendicular to a longer floor plan dimension. This assumption is imperative since different drift of frames in the same story can be obtained. This is important for strategic damper placement in the floor plan since drifts are used as placement indicator. Story drifts in the direction of larger floor plan dimension obtained from either rigid or semi-rigid floor assumptions show in-significant differences.

2. In this study, the MSSSA damper placement method shows the most consistent performance in reducing the story drifts as well as element damages. Even though the final result of damper placement is similar, the ODAM placement method has its limitation compared to MSSSA method that number of dampers used must be determined in the beginning, and dampers can only be swapped among stories of initially chosen frames. In R-Y and SR-X cases, the required numbers of dampers are 44 and 16 for both methods. However, MSSSA method indicates that 42 and 12 dampers are sufficient in SR-Y and R-X, respectively.

3. Both MSSSA and ODAM damper placement methods can improve the structure damage index and drift to meet the targeted performance.

4. Despite using the same number of dampers as in MSSSA and ODAM methods, uniform damper placement is less effective in improving the seismic performance of the structure.

5. It should be noted that the damper requirements in each direction are analyzed separately, despite that $2 \mathrm{D}$ earthquake is used. The final behavior of the structure should be represented with dampers in both directions installed.

\section{References}

1. SNI 1726:2012, Tata Cara Perencanaan Ketahanan Gempa untuk Struktur Bangunan Gedung dan Non Gedung, Badan Standardisasi Nasional, 2012. (in Indonesian).

2. SNI 2847:2013, Persyaratan Beton Struktural untuk Bangunan Gedung, Badan Standardisasi Nasional, 2013. (In Indonesian).

3. ASCE 7-10, Minimum Design Loads for Buildings and Other Structures, American Society of Civil Engineers, 2016.

4. Teal, E.J., Seismic Drift Control and Building Periods, Engineering Journal, 15(2), 1978, pp. 3038.

5. Pudjisuryadi, P., Lumantarna, B., Hermawan, T.F., and Gunawan, T.T., Seismic Performance of Existing Building Retrofitted with VSL-Gensui Damper, Civil Engineering Dimension, 20(2), 2018, pp. 86-90, doi: 10.9744/ced.20.2.86-90.

6. Hwang, J., Huang, Y., and Hung, Y., Analytical and Experimental Study of Toggle-Brace-Damper Systems, Journal of Structural Engineering, 131(7), 2005, pp. 1035-1043, doi: 10.1061/(ASCE) 0733-9445(2005)131:7(1035).

7. García, D.L., A Simple Method for the Design of Optimal Damper Configurations in MDOF Structures, Earthquake Spectra,17(3), 2001, pp. 387398, doi: 10.1193/1.1586180.

8. Angkasaputra, K., Sebastiano, F., Pudjisuryadi, P. and Lumantarna, B., Perbandingan Pengaruh Metode Penempatan Damper terhadap Kinerja Seismik Struktur, Dimensi Pratama Teknik Sipil, 7(2), 2018, pp. 144-152. (in Indonesian).

9. Leu, L.J. and Chang, J.T., Optimal Allocation of Non-linear Viscous Dampers for Three-dimensional Building Structures, Procedia Engineering, 
14, 2011 pp. 2489-2497, doi: 10.1016/j.proeng. 2011.07.313.

10. Andini, E., Goenawan, R.A., Pudjisuryadi, P. and Lumantarna, B., Perbandingan Metode Penempatan VSL Gensui Damper terhadap Ketidakberaturan Vertikal Tingkat Lunak, Dimensi Pratama Teknik Sipil, 8(2), 2019, pp. 267-273. (in Indonesian).
11. Computers \& Structures, Inc., CSI Analysis Reference Manual, Berkeley, California, USA, 2016.

12. Susanto, A., Non-Linear Time History Seismic Analysis with VSL Gensui Dampers in ETABS, VSL Hongkong Limited, Hongkong, 2011.

13. ACMC 2001, Asian Concrete Model Code Level 1 \& 2 Documents, International Committee on Concrete Model Code for Asia, 2001. 